Research Paper

\title{
Effects of Therapeutic Doses of Celecoxib on Several Physiological Parameters of Cultured Human Osteoblasts
}

\author{
Víctor J. Costela-Ruiz ${ }^{1,2}$, Lucia Melguizo-Rodríguez ${ }^{1,2}$, Rebeca Illescas-Montes ${ }^{1,2}$, Javier

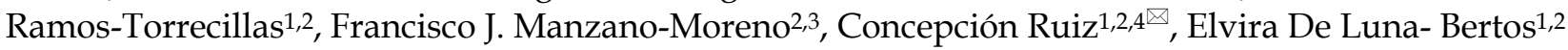 \\ 1. Biomedical Group (BIO277). Department of Nursing, Faculty of Health Sciences. University of Granada, Avda. Ilustración 60, 18016. Granada, Spain. \\ 2. Instituto Investigación Biosanitaria, ibs.Granada, C/ Doctor Azpitarte 4, $4^{\mathrm{a}}$ planta, 18012. Granada, Spain. \\ 3. Biomedical Group (BIO277). Department of Stomatology, School of Dentistry, University of Granada, Colegio Máximo, Campus Universitario de Cartuja \\ 18071. Granada, Spain \\ 4. Institute of Neuroscience, University of Granada, Centro de Investigación Biomédica (CIBM). Parque de Tecnológico de la Salud (PTS) Avda. del \\ Conocimiento S/N, 18016. Armilla, Granada, Spain. \\ $\square$ Corresponding author: Concepción Ruiz. Faculty of Health Sciences. University of Granada. Avda. De la Ilustración 60, 18016. Granada, Spain. e-mail: \\ crr@ugr.es
}

(c) The author(s). This is an open access article distributed under the terms of the Creative Commons Attribution License (https://creativecommons.org/licenses/by/4.0/). See http:/ /ivyspring.com/terms for full terms and conditions.

Received: 2019.06.24; Accepted: 2019.08.13; Published: 2019.09.20

\begin{abstract}
Non-steroidal anti-inflammatory drugs (NSAIDs), including cyclooxygenase-2 (COX-2)-selective NSAIDs, are associated with adverse effects on bone tissue. These drugs are frequently the treatment of choice but are the least studied with respect to their repercussion on bone. The objective of this study was to determine the effects of celecoxib on cultured human osteoblasts. Human osteoblasts obtained by primary culture from bone samples were treated with celecoxib at doses of $0.75,2$, or $5 \mu \mathrm{M}$ for $24 \mathrm{~h}$. The MTT technique was used to determine the effect on proliferation; flow cytometry to establish the effect on cell cycle, cell viability, and antigenic profile; and real-time polymerase chain reaction to measure the effect on gene expressions of the differentiation markers RUNX2, alkaline phosphatase (ALP), osteocalcin (OSC), and osterix (OSX). Therapeutic doses of celecoxib had no effect on osteoblast cell growth or antigen expression but had a negative impact on the gene expression of RUNX2 and OSC, although there was no significant change in the expression of ALP and OSX. Celecoxib at therapeutic doses has no apparent adverse effects on cultured human osteoblasts and only inhibits the expression of some differentiation markers. These characteristics may place this drug in a preferential position among NSAIDs used for analgesic and anti-inflammatory therapy during bone tissue repair.
\end{abstract}

Key words: celecoxib, osteoblasts, COX-2 selective NSAIDs, osteoblast differentiation, bone.

\section{Introduction}

Non-steroidal anti-inflammatory drugs (NSAIDs) include a large group of drugs that inhibit the cyclooxygenase enzyme (COX). These are divided between non-selective and selective inhibitors of COX-2 and are widely used in clinical practice to control pain and inflammation, especially in orthopedics and bone surgery $(1,2)$.

Various in vitro studies have found that NSAIDs exert adverse effects on the physiology of osteoblasts, including: inhibition of their proliferative capacity and cell differentiation; alteration of their antigenic profile; and modulation of the gene expression of markers involved in cell growth and maturation and bone mineralization (3-9). In parallel, various in vivo studies have shown that these drugs affect bone tissue though a delay in bony callus formation in fractures $(10,11)$ or a loss of bone mineral density (12), among others. However, research to date has mainly focused on non-selective NSAIDs.

Studies on the effect of COX-2 selective NSAIDs 
on bone tissue have largely been conducted in animal models and murine cell lines (13). There are currently no conclusive data on celecoxib, a potent selective NSAID mainly used in orthopedics and rheumatology. Some authors reported its adverse effects on bone formation in animal models (14), whereas others observed no celecoxib-related bone involvement (15).

The objective of this study was to determine the impact of celecoxib on cultured human osteoblasts by analyzing the effect of different celecoxib doses on the growth, antigenic profile, and gene expression of human osteoblasts obtained by primary culture from bone samples.

\section{Material and methods}

\section{Primary Human Osteoblast}

Human bone tissue was obtained from the Department of Stomatology of the University of Granada. All participants provided written informed consent to participate in this study, which was approved by the Ethical Committee of the University of Granada (Reg. No. 524/CEIH/2018). Primary osteoblasts were harvested from anonymous tissue in bone chips gathered during mandibular osteotomy or the surgical removal of lower wisdom teeth. We included a total of 3 donors in order to do all the assays for triplicate; 2 male and 1 female (30, 26 and 27 years old respectively). These cells were collected and cultured according to a standardized protocol (9), establishing three cell lines of primary culture human osteoblasts cultured. Cells were cultured until passage 4 to 6 before the treatment.

\section{Treatments}

The osteoblastic cell lines were treated for $24 \mathrm{~h}$ with celecoxib (Sigma, St Louis, MO, USA) at doses of $0.75,2$, or $5 \mu \mathrm{M}$; untreated cells served as controls.

\section{Cell proliferation}

Cell proliferation was determined by the MTT method as reported by Illescas-Montes et al. (16). Osteoblasts were seeded at $1 \times 10^{4}$ cells $/ \mathrm{mL}$ per well into a 96-well plate without fetal bovine serum (FBS) and cultured at $37^{\circ} \mathrm{C}$ for $24 \mathrm{~h}$. The medium was then replaced with Dulbecco's Modified Eagle medium (DMEM) containing celecoxib at a dose of $0.75,2$, or 5 $\mu \mathrm{M}$. After $24 \mathrm{~h}$, the medium was replaced with DMEM $\begin{array}{llll}\text { containing } & 0.5 & \mathrm{mg} / \mathrm{mL} & \text { MTT }\end{array}$ (3-(4,5-Dimethylthiazol-2-yl)-2,5-diphenyltetrazolium bromide) supplied by Sigma and incubated for $4 \mathrm{~h}$. Cellular reduction of the MTT tetrazolium ring resulted in the formation of a dark-purple water-insoluble deposit of formazan crystals. After incubation, the medium was aspirated and DMSO was added to dissolve the formazan crystals. Absorbance was measured at $570 \mathrm{~nm}$ with a spectrophotometer (SunriseTM, Tecan, Männedorf, Switzerland).

\section{Cell Cycle}

Cultured human osteoblast cells treated with $0.75,2$, or $5 \mu \mathrm{M}$ celecoxib or with no NSAID treatment (controls) were detached from the culture flask with a solution of $0.05 \%$ trypsin (Sigma) and $0.02 \%$ ethylene diamine tetraacetic acid (EDTA) (Sigma) and were then washed and suspended in phosphate buffered saline (PBS) and prepared for the cell cycle study by flow cytometry as previously reported (16).

\section{Apoptosis and necrosis analysis}

Cultured human osteoblast cells treated with $0.75,2$, or $5 \mu \mathrm{M}$ celecoxib for $24 \mathrm{~h}$ or with no NSAID treatment (controls) were detached from the culture flask, washed, suspended in $300 \mu \mathrm{L}$ PBS, and then labeled with annexin $\mathrm{V}$ and propidium iodide (PI) (Immunostep S.L., Salamanca, Spain). We incubated $100 \mu \mathrm{L}$ aliquots of the cell suspension with $5 \mu \mathrm{L}$ annexin $\mathrm{V}$ and $5 \mu \mathrm{L}$ PI for $30 \mathrm{~min}$ at $4{ }^{\circ} \mathrm{C}$ in the dark. Cells were then washed, suspended in $1 \mathrm{~mL}$ PBS, and immediately analyzed in a flow cytometer with argon laser (Fasc Vantage Becton Dickinson, Palo Alto, CA) at a wavelength of $488 \mathrm{~nm}$ to determine the percentage of fluorescent cells. We calculated the percentage of annexin-positive (apoptotic) cells and PI-positive (necrotic) cells from counts of 2,000-3,000 cells.

\section{Antigenic phenotype}

Antigenic phenotype was studied by flow cytometry at $24 \mathrm{~h}$ of culture after treatment with 0.75 , 2 , or $5 \mu \mathrm{M}$ celecoxib. Untreated cells served as controls. Cells were detached from the cultured flask with $0.4 \%(\mathrm{w} / \mathrm{v})$ EDTA solution, washed, and suspended in PBS at $2 \times 10^{4}$ cells $/ \mathrm{mL}$. Cells were labeled by direct staining with the monoclonal antibodies (MAbs) CD54, CD80, CD86, and HLA-DR (ICAM-1 monoclonal antibody [MEM-111], FITC; human CD80 [B7-1, BB1], FICT; human CD86 [B7-2, B70], FICT; and anti-human HLA-DR [Clas II], FICT; respectively, from Invitrogen, Thermo Fisher Scientific, Spain). Cells were subsequently analyzed by flow cytometry (FASC Canton II, SE Becton Dickinson, Palo Alto, CA) as previously described Melguizo-Rodriguez et al. (8).

\section{Gene expression determination by real-time polymerase chain reaction (RT-qPCR)}

Gene expression analysis was performed as described Bustin et al. (17), Manzano-Moreno et al. 
(18) and Ragni et al. (19):

\section{RNA extraction and cDNA synthesis (reverse transcription)}

After $24 \mathrm{~h}$ of culture with Celecoxib treatment (untreated cells served as controls), cells were detached from the culture flask using $0.05 \%$ trypsin-EDTA solution (Sigma) and individually harvested. mRNA was extracted using a silicate gel technique in the QiagenRNeasy extraction kit (Qiagen Inc., Hilden, Germany), which includes a DNAse digestion step. The amount of extracted mRNA was measured by UV spectrophotometry at $260 \mathrm{~nm}$ (Eppendorf AG, Hamburg, Germany), and contamination with proteins was determined according to the 260/280 ratio. An equal amount of RNA ( $1 \mu \mathrm{g}$ of total RNA in $40 \mu \mathrm{l}$ of total volume) was reverse-transcribed to cDNA and amplified by PCR using the iScript ${ }^{\mathrm{TM}}$ cDNA Synthesis Kit (Bio-Rad laboratories, Hercules, CA, USA), following the manufacturer's instructions.

\section{Real-time polymerase chain reaction (RT-PCR)}

Primers were designed using NCBI-nucleotide library and Primer3-design (Table 1) to detect mRNA of RUNX2, OSC, OSX, and ALP. All were matched to the mRNA sequences of target genes (NCBI Blast software).

Final results were normalized using ubiquitin $C$ (UBC), peptidylprolyl isomerase A (PPIA), and ribosomal protein S13 (RPS13) as stable housekeeping genes.

Quantitative RT-PCR (q-RT-PCR) was conducted using the SsoFast ${ }^{\mathrm{TM}}$ EvaGreen ${ }^{\circledR}$ Supermix Kit (Bio-Rad laboratories) and following the manufacturer`s instructions. Samples were amplified in 96-well microplates in an IQ5-Cycler (Bio-Rad laboratories) at a specific annealing temperature for each gene, ranging from 60 to $65{ }^{\circ} \mathrm{C}$, and at an elongation temperature of $72{ }^{\circ} \mathrm{C}$ over 40 cycles. PCR reactions were carried out in a final volume of $20 \mu \mathrm{L}$, with $5 \mu \mathrm{L}$ of cDNA sample and $2 \mu \mathrm{L}$ of each primer. $\mathrm{Ct}$ values were plotted against log cDNA dilution to construct standard curves for each target gene. After each RT-PCR, a melting profile was created and agarose gel electrophoresis was conducted in each sample to rule out nonspecific PCR products and primer dimers. The comparative $\mathrm{Ct}$ method was employed for the relative quantification of gene expression. The mRNA concentration for each gene was expressed as ng of mRNA per average ng of housekeeping mRNAs. The cDNA from individual cell experiments was analyzed in triplicate RT-PCR studies.
Table 1. Primer sequences for the amplification of cDNA by real-time PCR.

\begin{tabular}{|c|c|c|c|}
\hline Gene & Sense primer & Antisense primer & Amplicon (bp) \\
\hline \multirow{4}{*}{ RUNX2 } & 50 & 50 & \\
\hline & -TGGTTAATCTCCGCA & -ACTGTGCTGAAGAG & 143 \\
\hline & GGTCAC-30 & GCTGTTTG-30 & \\
\hline & 50 & 50 & \\
\hline \multirow[t]{3}{*}{ OsX } & -TGCCTAGAAGCCCTG & -TTTAACTTGGGGCCT & 205 \\
\hline & AGAAA-30 & TGAGA-30 & \\
\hline & 50 & 50 & \\
\hline \multirow[t]{3}{*}{ ALP } & -CCAACGTGGCTAAG & -TGGGCATTGGTGTTG & 175 \\
\hline & AATGTCATC-30 & TACGTC-30 & \\
\hline & 50 & 50 & \\
\hline \multirow[t]{2}{*}{ OSC } & -CCATGAGAGCCCTC & -GGTCAGCCAACTCGT & 258 \\
\hline & АСАСТСС-30 & CACAGTC-30 & \\
\hline
\end{tabular}

\section{Statistical analysis}

$\mathrm{R}$ software (version 2.9.2, Auckland, New Zealand) was used for data analyses. Mean values ( \pm standard deviation) were calculated for each variable. A two-way repeated-measures analysis of variance (ANOVA) was performed to analyze the effects on proliferation, cell cycle, apoptosis/necrosis induction, and gene expression, considering treatment (celecoxib), time ( $24 \mathrm{~h})$, and concentration $(0.75,2$, or 5 $\mu \mathrm{M})$. When significant interactions were identified, the Bonferroni correction was applied for planned pair-wise comparisons. $\mathrm{P} \leq 0.05$ was considered significant. Antigenic profiles were compared using the Student's t-test. $\mathrm{P} \leq 0.05$ was considered statistically significant in all tests. At least three experiments were performed in all assays and for each culture.

\section{Results}

\section{Effect of celecoxib on osteoblast proliferation}

Figure 1 depicts the effect of celecoxib on cell proliferation after $24 \mathrm{~h}$ of treatment with doses of 0.75 , 2 , or $5 \mu \mathrm{M}$. No significant changes in the proliferative capacity of osteoblasts were observed after treatment at any assayed dose of the drug.

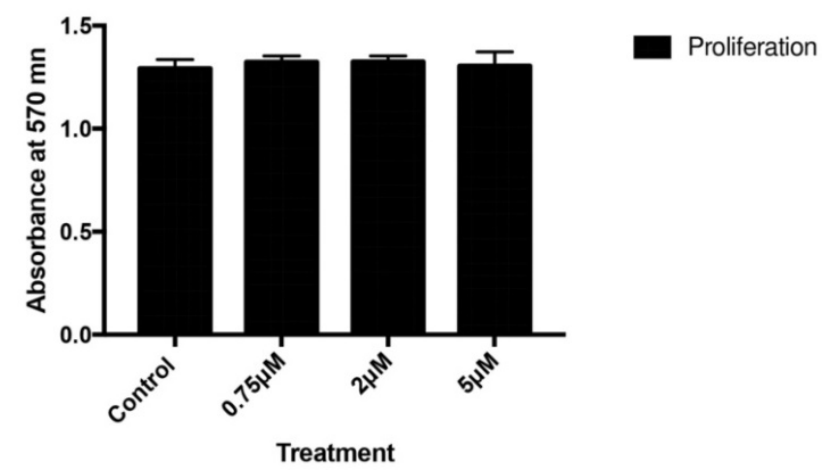

Figure 1. Effects of different celecoxib doses $(0.75,2$, or $5 \mu \mathrm{M})$ on osteoblast proliferation after $24 \mathrm{~h}$ of treatment. Data are expressed as means $+/ \pm \mathrm{SD}$. Analysis of variance was used to compare data between each treatment and control culture. 


\section{Effect of celecoxib on osteoblast cell cycle}

Treatment with $0.75,2$, or $5 \mu \mathrm{M}$ celecoxib for $24 \mathrm{~h}$ produced no significant changes in osteoblast cell cycle, finding similar cell percentages in G0/G1, $\mathrm{G} 2 / \mathrm{M}$, and $\mathrm{S}$ phases to those observed in the controls (Figure 2).

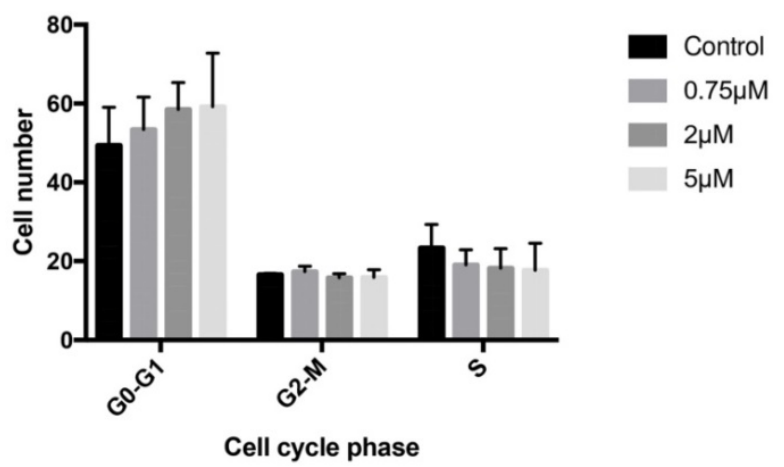

Figure 2. Effects of celecoxib on cell cycle determined by flow cytometry. Cultured cells were treated for $24 \mathrm{~h}$ with $0.75,2$, or $5 \mu \mathrm{M}$ celecoxib. The control group was not treated. G0/G1, S, and G2/M represent the percentage of cells distributed among these phases after treatment, as determined by flow cytometry. Experiments were repeated at least three times.

\section{Effect of celecoxib on osteoblast in apoptosis}

No signs of cell apoptosis and/or necrosis were detected after osteoblast treatment with $0.75,2$, or 5 $\mu \mathrm{M}$ celecoxib for $24 \mathrm{~h}$ (Table 2 ).

3A

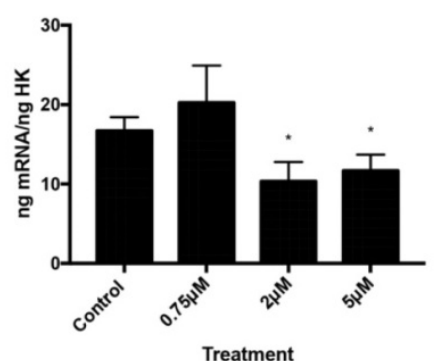

Table 2. Results of apoptosis assay in cultured cells treated for 24 $\mathrm{h}$ with celecoxib doses of $0.75,2$, or $5 \mu \mathrm{M}$.

\begin{tabular}{llllllllll}
\hline & \multicolumn{3}{l}{ Necrotic cells } & \multicolumn{3}{l}{ Viable cells } & \multicolumn{4}{c}{ Apoptotic cells } \\
\cline { 2 - 9 } & \multicolumn{3}{l}{ Mean P Value SD } & \multicolumn{2}{l}{ Mean } & P Value SD & Mean & P Value SD \\
\hline Control & 0,633 & - & 0,321 & 91,233 & - & 10,404 & 8,133 & - & 10,082 \\
0,75 & 0,466 & 0,519 & 0,251 & 91,666 & 0,952 & 5,396 & 7,866 & 0,970 & 5,492 \\
2 & 0,366 & 0,230 & 0,057 & 83,566 & 0,295 & 3,655 & 16,066 & 0,269 & 3,611 \\
\hline
\end{tabular}

\section{Effect of celecoxib on the expression of RUNX2, ALP, OSX, and OSC genes}

Figures 3 and 4 depict the q-RT-PCR results for the expression of osteoblast differentiation makers RUNX2, ALP, OSX, and OSC. After $24 \mathrm{~h}$ of treatment at a dose of 2 or $5 \mu \mathrm{M}$, osteoblast expression of RUNX2 (figure 3A) and OSC (figure 3B) was significantly lower versus controls (Figure 3 ).

However, no changes in the expression of these markers were observed at the lowest dose $(0.75 \mu \mathrm{M})$. ALP (Figure 4A) and OSX (Figure 4B) expression did not change after treatment with celecoxib at any assayed dose (Figure 4).

\section{Effect of celecoxib on phenotypic profile}

Expression of CD54, CD80, CD86, or HLA-DR genes did not significantly differ between cells treated for $24 \mathrm{~h}$ with $0.75,2$, or $5 \mu \mathrm{M}$ celecoxib and untreated control cells (Figure 5).

\section{B}

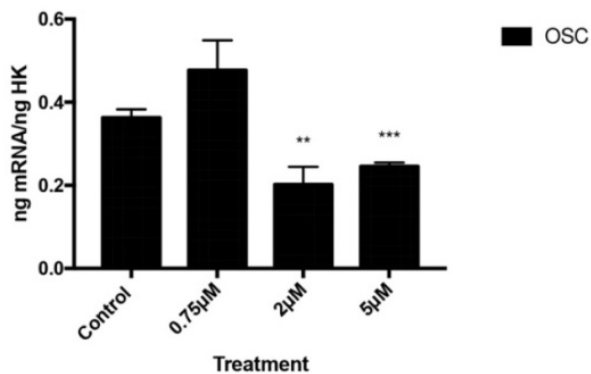

Figure 3. Expression of RUNX2 (3A) and OSC (3B) genes after $24 \mathrm{~h}$ treatment with $0.75,2$, or $5 \mu \mathrm{M}$. Data expressed as percentage expression with respect to control \pm SD. $(* * * \mathrm{P} \leq 0.0001 ; * * \mathrm{P} \leq 0.01 ; * \mathrm{P} \leq 0.05)$.

$4 \mathrm{~A}$

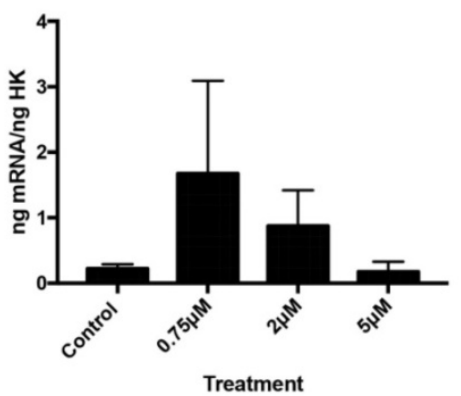

$4 \mathrm{~B}$

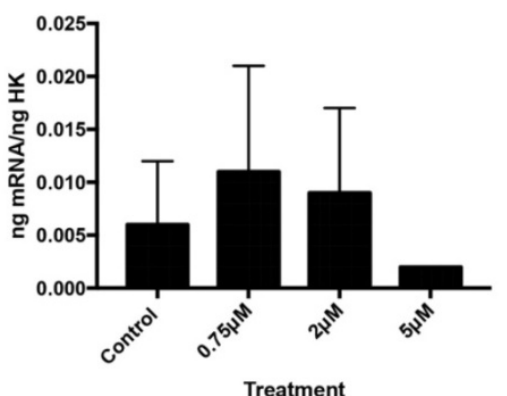

osx

Figure 4. Expression of ALP $(4 \mathrm{~A})$ and OSX $(4 \mathrm{~B})$ genes after $24 \mathrm{~h}$ treatment with $0.75,2$, or $5 \mu \mathrm{M}$. Data expressed as percentage expression with respect to control \pm SD. $(* * *$ $\mathrm{P} \leq 0.0001 ; * * \mathrm{P} \leq 0.01 ; * \mathrm{P} \leq 0.05)$. 


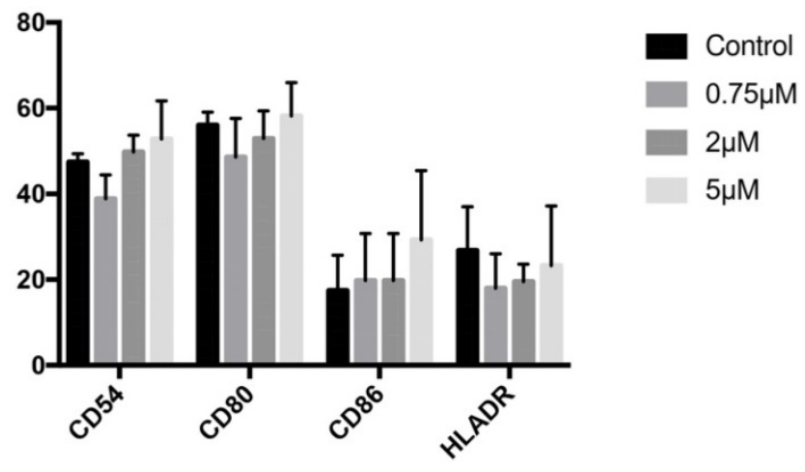

Figure 5. Expression of CD54, CD80, CD86, and HLA-DR genes by cells treated for $24 \mathrm{~h}$ with celecoxib $(0.75,2$, or $5 \mu \mathrm{M})$. Data are expressed as percentage expression with respect to control \pm SD.

\section{Discussion}

Treatment of primary culture human osteoblasts with therapeutic doses of celecoxib, a COX-2 selective NSAID, had no significant effects on their antigenic profile, growth, proliferation, or cell cycle and produced no signs of cell death. However, this treatment reduced the gene expression of RUNX2 and OSC, two biological markers with an important role in osteoblast differentiation, whereas no changes were observed in the expression of ALP or OSX. These results suggest that celecoxib, unlike other NSAIDs (7), acts on the expression of some of the genes involved in cell differentiation but does not affect other cell parameters such as growth or antigen expression.

The finding that celecoxib at $0.75,2$, or $5 \mu \mathrm{M}$ (within the therapeutic range) has no effect on osteoblast growth is in line with previously published results. For instance, proapoptotic effects were observed after the treatment of MG63 human osteoblast cells with celecoxib at a dose of $50 \mu \mathrm{M}$ but not at a dose of 2 or $10 \mu \mathrm{M}(20)$, and no changes in the proliferation or viability of the murine pre-osteoblastic cell line MC3T3-E1 were observed after treatment with celecoxib at a dose of $20 \mu \mathrm{M}$ (21). However, celecoxib at doses of 0.1 or $1 \mu \mathrm{M}$ was found to inhibit cell proliferation and arrest the cell cycle in G0/G1 phase in cultured human osteoblasts (4) and in mesenchymal cells derived from mouse bone marrow (22). This last effect has been reported for other non-selective NSAIDs, in which the drug dose plays an important role $(5,6,23)$.

The above effects of celecoxib on osteoblasts in vitro are closely related to observations in experimental animals. Thus, Kasukawa et al. (15) treated ovariectomized mice at a dose of $4 \mathrm{mg} / \mathrm{kg}$ for four weeks and found no change in bone formation but observed an effect on C- telopeptide, a marker related to resorption, a function carried out at bone level by osteoclasts. Liu et al. (24) treated Sprague Dawley rats with daily doses of $50 \mathrm{mg} / \mathrm{kg}$ celecoxib for two weeks and also observed no significant effect on bone formation.

Celecoxib does not appear to compromise bone healing, given that bone fusion was not altered by its administration at $10 \mathrm{mg} / \mathrm{kg} /$ day for eight weeks to rabbits after posterolateral intertransverse arthrodesis (25). In another study, Brown et al. (26) treated male rats with $3 \mathrm{mg} / \mathrm{kg} /$ day celecoxib or $1 \mathrm{mg} / \mathrm{kg} /$ day indomethacin for four or eight weeks and found no difference in healing versus controls for the celecoxib-treated rats but a delay in healing for the indomethacin-treated animals. Osteoblasts are directly involved in bone fracture healing, being the cells responsible for bone formation and repair during this process $(27,28)$.

Osteoblasts have a characteristic antigenic profile, including antigens whose expression is modulated by the degree of cell maturation and/or the presence of certain biomolecules such as proinflammatory cytokines $(29,30)$. Various NSAIDs have been found to modulate the expression of CD54, CD80, and HLA-DR $(5,23,31)$. However, celecoxib treatment did not change the expression of these markers at any dose assayed in the present study.

Although no effect on osteoblast growth or antigenic profile was observed, celecoxib doses of 2 and $5 \mu \mathrm{M}$ inhibited the gene expression of differentiation markers RUNX2 and OSC but not ALP or OSX. Matsuyama et al. (21) reported that celecoxib doses between 0.02 and $20 \mu \mathrm{M}$ inhibit osteoblast differentiation in the MC3T3-E1 line but do not alter cell viability, indicating that negative effects on bone tissue at doses above $0.02 \mu \mathrm{M}$ may be attributable to the inhibition of osteoblast differentiation. Nagano et al. (32) found that $50 \mu \mathrm{M}$ celecoxib can inhibit the expression of RUNX2 mRNA in the same cell line (MC3T3-E1).

OSC is a peptide hormone secreted by osteoblasts during bone formation at a late stage of osteoblast differentiation, and it participates in bone mineralization and osteoclast activity regulation (33). It is transcribed by the RUNX2/CBFA1 complex (34). This raises the question whether the decrease in OSC expression is directly caused by the celecoxib treatment or is indirectly produced by its inhibitory effect on the expression of RUNX2. Celecoxib was found to negatively affect bone formation in mice, observing a reduced expression of OSC mRNA in bone marrow samples from those administered with $30 \mathrm{mg} / \mathrm{kg}$ celecoxib twice daily for five days (14).

Selective and non-selective NSAIDs are used in the treatment of heterotopic ossification, which can appear after surgery, especially arthroplasty. This 
ossification of soft tissue results from an abnormal differentiation to bone cells of mesenchymal stem cells. NSAIDs are used to inhibit the bone differentiation of progenitors and prevent this surgical complication (35-38). These data may be related to our finding of a celecoxib-induced decrease in the gene expression of markers such as RUNX2 and OSC. However, celecoxib treatment was found to reduce inflammation in rats with collagen-induced arthritis, and high doses of this drug prevented bone loss adjacent to inflamed joints and significantly decreased bone resorption but had no impact on bone formation (39). The authors concluded that celecoxib had a preventive effect on both growth plate destruction and bone loss adjacent to inflamed joints in this arthritis model.

In summary, our study shows that therapeutic doses of celecoxib, ranging from 0.75 to $5 \mu \mathrm{M}$, have no adverse effects on osteoblast growth or antigen expression but reduce the gene expression of RUNX2 and OSC. It is not possible to establish whether this reduction affects physiological bone development given the absence of changes in the expression of ALP or OSX, also involved in differentiation. Further studies are required to determine whether celecoxib interferes with the maturation of osteoblasts and therefore with their function at bone tissue level. Nevertheless, our results indicate that this NSAID is a good option for analgesic and anti-inflammatory therapy during bone tissue repair.

\section{Acknowledgements}

This study was supported by research group BIO277 (Junta de Andalucía) and Department of Nursing (University of Granada). The work outlined in this article has been supported by the Spanish Ministry of Education under FPU fellowship reference FPU15-05635 and FPU16-04141.

\section{Competing Interests}

The authors have declared that no competing interest exists.

\section{References}

1. [Internet] Flórez https://www.elsevier.com/books/farmacologia-humana/florez-beledo/97884-458-2316-3.

2. [Internet] Saad J. http://www.ncbi.nlm.nih.gov/books/NBK526006/

3. [Internet] Evans y Butcher. https://pdfs.semanticscholar.org/cac9/b8662571424bbfead0991d70e4f7fcbb5 514.pdf

4. Chang J-K, Li C-J, Liao H-J, Wang C-K, Wang G-J, Ho M-L. Anti-inflammatory drugs suppress proliferation and induce apoptosis through altering expressions of cell cycle regulators and pro-apoptotic factors in cultured human osteoblasts. Toxicology. 2009 Apr 28;258(2-3):148-56.

5. De Luna-Bertos E, Ramos-Torrecillas J, García-Martínez O, Guildford A, Santin M, Ruiz C. Therapeutic Doses of Nonsteroidal Anti-Inflammatory Drugs Inhibit Osteosarcoma MG-63 Osteoblast-Like Cells Maturation, Viability, and Biomineralization Potential. ScientificWorldJournal [Internet]. 2013 Sep 19 [cited 2018 Nov 20];2013. Available from: https://www.ncbi.nlm.nih.gov/pmc/articles/PMC3793504/

6. De Luna-Bertos E, Ramos-Torrecillas J, Manzano-Moreno FJ García-Martínez O, Ruiz C. Effects on growth of human osteoblast-like cells of three nonsteroidal anti-inflammatory drugs: metamizole, dexketoprofen, and ketorolac. Biol Res Nurs. 2015 Jan;17(1):62-7.

7. García-Martínez O, De Luna-Bertos E, Ramos-Torrecillas J, Manzano-Moreno FJ, Ruiz C. Repercussions of NSAIDS drugs on bone tissue: the osteoblast. Life Sci. 2015 Feb 15;123:72-7.

8. Melguizo-Rodríguez L, Costela-Ruiz VJ, Manzano-Moreno FJ, Illescas-Montes R, Ramos-Torrecillas J, García-Martínez O, et al. Repercussion of nonsteroidal anti-inflammatory drugs on the gene expression of human osteoblasts. PeerJ. 2018;6:e5415.

9. Manzano-Moreno FJ, Costela-Ruiz VJ, Melguizo-Rodríguez L, Illescas-Montes R, García-Martínez O, Ruiz C, et al. Inhibition of VEGF gene expression in osteoblast cells by different NSAIDs. Arch Oral Biol. 2018 Aug;92:75-8.

10. Burd TA, Hughes MS, Anglen JO. Heterotopic ossification prophylaxis with indomethacin increases the risk of long-bone nonunion. J Bone Joint Surg Br. 2003 Jul;85(5):700-5.

11. Bhattacharyya $\mathrm{T}$, Levin $\mathrm{R}$, Vrahas MS, Solomon $\mathrm{DH}$ Nonsteroidal antiinflammatory drugs and nonunion of humeral shaft fractures. Arthritis Rheum. 2005 Jun 15;53(3):364-7.

12. Pountos I, Georgouli T, Calori GM, Giannoudis PV. Do nonsteroidal anti-inflammatory drugs affect bone healing? A critical analysis. ScientificWorldJournal. 2012;2012:606404.

13. Goodman S, Ma T, Trindade M, Ikenoue T, Matsuura I, Wong N, et al. COX-2 selective NSAID decreases bone ingrowth in vivo. J Orthop Res. 2002 Nov;20(6):1164-9.

14. Nakai K, Tanaka S, Sakai A, Nagashima M, Tanaka M, Otomo H, et al. Cyclooxygenase-2 selective inhibition suppresses restoration of tibial trabecular bone formation in association with restriction of osteoblast maturation in skeletal reloading after hindlimb elevation of mice. Bone. 2006 Jul;39(1):83-92.

15. Kasukawa Y, Miyakoshi N, Srivastava AK, Nozaka K, Maekawa S, Baylink DI, et al. The selective cyclooxygenase- 2 inhibitor celecoxib reduces bone resorption, but not bone formation, in ovariectomized mice in vivo. Tohoku J Exp Med. 2007 Mar;211(3):275-83.

16. Illescas-Montes R, Melguizo-Rodríguez L, Manzano-Moreno FJ, García-Martínez O, Ruiz C, Ramos-Torrecillas J. Cultured Human Fibroblast Biostimulation Using a $940 \mathrm{~nm}$ Diode Laser. Materials (Basel). 2017 Jul 13;10(7).

17. Bustin SA, Benes V, Garson JA, Hellemans J, Huggett J, Kubista M, et al. The MIQE Guidelines: Minimum Information for Publication of Quantitative Real-Time PCR Experiments. Clinical Chemistry. 2009 Apr 1;55(4):611-22.

18. Manzano-Moreno FJ, Ramos-Torrecillas J, Melguizo-Rodríguez L, Illescas-Montes R, Ruiz C, García-Martínez O. Bisphosphonate Modulation of the Gene Expression of Different Markers Involved in Osteoblast Physiology: Possible Implications in Bisphosphonate-Related Osteonecrosis of the Jaw. Int J Med Sci. 2018:15(4):359-67.

19. Ragni E, Viganò M, Rebulla P, Giordano R, Lazzari L. What is beyond a qRT-PCR study on mesenchymal stem cell differentiation properties: how to choose the most reliable housekeeping genes. J Cell Mol Med. 2013 Jan;17(1):168-80

20. Kolar P, Lach S, Gaber T, Maschmeyer P, Dziurla R, Tripmacher R, et al. Effects of celecoxib on the expression of osteoprotegerin, energy metabolism and cell viability in cultured human osteoblastic cells. Clin Exp Rheumatol. 2009 Feb;27(1):99-107

21. Matsuyama A, Higashi S, Tanizaki S, Morotomi T, Washio A, Ohsumi T, et al. Celecoxib inhibits osteoblast differentiation independent of cyclooxygenase activity. Clin Exp Pharmacol Physiol. 2018 Jan;45(1):75-83.

22. Chang J-K, Li C-J, Wu S-C, Yeh C-H, Chen C-H, Fu Y-C, et al. Effects of anti-inflammatory drugs on proliferation, cytotoxicity and osteogenesis in bone marrow mesenchymal stem cells. Biochem Pharmacol. 2007 Nov 1;74(9):1371-82.

23. Díaz-Rodríguez L, García-Martínez O, Morales MA-, Rodríguez-Pérez L, Rubio-Ruiz B, Ruiz C. Effects of indomethacin, nimesulide, and diclofenac on human MG-63 osteosarcoma cell line. Biol Res Nurs. 2012 Jan;14(1):98-107.

24. Liu Y, Cui Y, Chen Y, Gao X, Su Y, Cui L. Effects of dexamethasone, celecoxib, and methotrexate on the histology and metabolism of bone tissue in healthy Sprague Dawley rats. Clin Interv Aging. 2015;10:1245-53.

25. Long J, Lewis S, Kuklo T, Zhu Y, Riew KD. The effect of cyclooxygenase-2 inhibitors on spinal fusion. J Bone Joint Surg Am. 2002 Oct:84-A(10):1763-8.

26. Brown KM, Saunders MM, Kirsch $\mathrm{T}$, Donahue HJ, Reid JS. Effect of COX-2-specific inhibition on fracture-healing in the rat femur. J Bone Joint Surg Am. 2004 Jan;86-A(1):116-23.

27. Capulli M, Paone R, Rucci N. Osteoblast and osteocyte: games without frontiers. Arch Biochem Biophys. 2014 Nov 1;561:3-12.

28. Bahney CS, Zondervan RL, Allison P, Theologis A, Ashley J, Ahn J, et al. The Cellular Biology of Fracture Healing. J Orthop Res. 2018 Oct 28;

29. Ruiz C, Reyes-Botella C, García-Martínez O, Montes MJ. Modulation of antigenic phenotype by IL-1beta, IFNgamma and TGFbeta on cultured human decidual stromal cells. Biosci Rep. 2004 Feb;24(1):55-62.

30. Pérez E, García-Martínez O, Arroyo-Morales M, Reyes-Botella C, Ruiz C. Modulation of antigenic phenotype in cultured human osteoblast-like cells by FGFb, TGFbeta1, PDGF-BB, IL-2, IL-1beta, LPS and IFNgamma. Biosci Rep. 2006 Aug;26(4):281-9. 
31. Díaz-Rodríguez L, García-Martínez O, De Luna-Bertos E, Ramos-Torrecillas J, Ruiz C. Effect of ibuprofen on proliferation, differentiation, antigenic expression, and phagocytic capacity of osteoblasts. J Bone Miner Metab. 2012 Sep;30(5):554-60.

32. Nagano A, Arioka M, Takahashi-Yanaga F, Matsuzaki E, Sasaguri T. Celecoxib inhibits osteoblast maturation by suppressing the expression of Wnt target genes. J Pharmacol Sci. 2017 Jan;133(1):18-24.

33. Wei J, Karsenty G. An overview of the metabolic functions of osteocalcin. Rev Endocr Metab Disord. 2015 Jun;16(2):93-8.

34. Neve A, Corrado A, Cantatore FP. Osteocalcin: skeletal and extra-skeletal effects. J Cell Physiol. 2013 Jun;228(6):1149-53.

35. Neal B, Rodgers A, Dunn L, Fransen M. Non-steroidal anti-inflammatory drugs for preventing heterotopic bone formation after hip arthroplasty. Cochrane Database Syst Rev. 2000;(3):CD001160.

36. Goodman SB, Ma T, Mitsunaga L, Miyanishi K, Genovese MC, Smith RL. Temporal effects of a COX-2-selective NSAID on bone ingrowth. J Biomed Mater Res A. 2005 Mar 1;72(3):279-87.

37. Kan S-L, Yang B, Ning G-Z, Chen L-X, Li Y-L, Gao S-J, et al. Nonsteroidal Anti-inflammatory Drugs as Prophylaxis for Heterotopic Ossification after Total Hip Arthroplasty: A Systematic Review and Meta-Analysis. Medicine (Baltimore). 2015 May;94(18):e828.

38. Ranganathan K, Loder S, Agarwal S, Wong VW, Wong VC, Forsberg J, et al. Heterotopic Ossification: Basic-Science Principles and Clinical Correlates. J Bone Joint Surg Am. 2015 Jul 1;97(13):1101-11.

39. Tsuboi H, Nampei A, Matsui Y, Hashimoto J, Kawai S, Ochi T, et al. Celecoxib prevents juxta-articular osteopenia and growth plate destruction adjacent to inflamed joints in rats with collagen-induced arthritis. Mod Rheumatol. 2007 Apr 1;17(2):115-22. 